\title{
PENGARUH PENAMBAHAN VARIASI KONSENTRASI TEPUNG REBUNG PADA PEMBUATAN ROTI TAWAR TERHADAP KADAR SERAT, UMUR SIMPAN DAN UJI ORGANOLEPTIK
}

\author{
THE EFFECT OF ADDING VARIATIONS IN THE CONCENTRATION \\ OF BAMBOO SHOOT FLOUR IN MAKING BREAD TO FIBER CONTENT, \\ SHELF LIFE AND ORGANOLEPTIC TEST
}

\author{
Vefty Novita Putri, Yenni Okfrianti, Kamsiah \\ Politeknik Kesehatan Kementerian Kesehatan Bengkulu, Jurusan Gizi \\ Jalan Indragiri Nomor 3 Padang Harapan Bengkulu \\ veftynovitaputri11@gmail.com
}

\begin{abstract}
ABSTRAK
Roti Tawar tepung rebung merupakan produk makanan yang dibuat dari bahan baku roti tawar dengan penambahan variasi konsentrasi tepung rebung betung (Dendrocalamus asper). Tujuan dari penelitian ini adalah untuk menentukan pengaruh penambahan berbagai konsentrasi tepung rebung dalam pembuatan roti tawar terhadap kadar serat dan uji organoleptik. Metode Penelitian ini merupakan penelitian yang bersifat ekserimen menggunakan rancangan acak lengkap (RAL). Penilaian organoleptik dilakukan oleh panelis agak terlatih sebanyak 40 orang yaitu mahasiswa Jurusan Gizi Poltekkes Kemenkes Bengkulu. Setelah didapat roti tawar yang paling disukai panelis maka dilanjutkan dengan uji kadar serat. Analisis hasil uji organoleptik menggunakan aplikasi statistik Uji Kruskal Wallis dengan tingkat signifikansi menggunakan $\mathrm{p}<0,05$ makan silanjutkan dengan Uji Man Whithey. Hasil Penelitian ini menunjukkan rata-rata panelis menyukai roti tawar penambahan tepung rebung formula $1(0 \%)$ dan $2(3 \%)$ yaitu 0 gram dan 10 gram tepung rebung dengan hasil kadar serat $0,60 \%$ dan 2,16\%. Saran setelah dilakukan uji organoleptik (warna, aroma,rasa dan tekstur) dapat diterima oleh panelis dengan kadar serat yang tinggi. Diharapkan produk roti tawar penambahan tepung rebung dapat dikenal oleh masyarakat luas dan disarankan pula masyarakat dapat mengkonsumsi sumber serat dari bahan pangan lainnya.
\end{abstract}

Kata kunci : Roti Tawar, tepung rebung, kadar serat, uji organoleptik

\begin{abstract}
Bread flour shoots are food products made from raw materials with the addition of white bread flour concentration variation shoots betung (Dendrocalamus asper). The purpose of this study was to determine the effect of adding various concentrations of bamboo shoots flour in making bread to the fiber content and organoleptic test. Research methodsThis is a research that is ekserimen using a completely randomized design (CRD). Organoleptic assessment carried out by the panelists somewhat trained 40 people as students Nutrition Department of Ministry of Health Polytechnic of Bengkulu. Having obtained the most preferred white bread panelists then continued with a fiber content test. Analysis of the results of organoleptic test using Kruskal Wallis statistical applications by using a
\end{abstract}


significance level of $p<0.05$ eat silanjutkan with Test Man Whithey. Research result This shows the average panelists liked the addition of white bread flour shoots formula $1(0 \%)$ and $2(3 \%)$ is 0 grams and 10 grams of flour shoots with the results of the fiber content of $0.60 \%$ and $2.16 \%$. Suggestionafter organoleptic (color, aroma, flavor and texture) can be accepted by the panelists with a high fiber content. It is expected that the addition of white bread flour products bamboo shoots can be recognized by the public and the public are also advised to consume a source of fiber than other foodstuffs.

\section{Keywords: Bread, flour bamboo shoots, fiber content, organoleptic}

\section{PENDAHULUAN}

Secara umum sayuran dan buahbuahan merupakan sumber berbagai vitamin, mineral, dan serat pangan. Masyarakat Indonesia balita dan anak usia sekolah dianjurkan untuk mengkonsumsi sayuran dan buah-buahan 300-400 gram per orang per hari dan bagi remaja dan orang dewasa sebanyak 400-600 gram per orang per hari. Sekitar dua-pertiga dari jumlah anjuran konsumsi tersebut adalah porsi sayur. Anjuran konsumsi sayuran lebih banyak daripada buah karena buah juga mengandung gula, ada yang sangat tinggi ada pula yang jumlahnya cukup (Kementrian Kesehatan RI, 2017).

Di dalam Studi Diet Total (2014) Konsumsi kelompok sayur dan olahan serta buah-buahan dan olahan masih rendah yaitu 57,1 gram per orang per hari dan 33,5 gram per orang per hari. Dalam kelompok sayur, sayuran hijau dikonsumsi paling banyak (79,1\%) dibandingkan sayur lainnya. Untuk kelompok buah-buahan dan olahan, buah pisang terbanyak dikonsumsi oleh penduduk $(15,1 \%)$ (Puspitasari, Julianti, Safitri, \& Permanasari, 2014). Salah satu komponen pangan yang cukup dapat sorotan adalah serat pangan. Serat pangan adalah makanan berbentuk karbohidrat kompleks yang banyak terdapat pada dinding sel tanaman pangan. Serat pangan tidak dapat dicerna dan tidak diserap oleh saluran pencernaan manusia, tetapi memiliki fungsi yang sangat penting bagi pemeliharaan kesehatan, pencegahan penyakit dan sebagai komponen penting dalam terapi gizi (Made Astawan dan Tutik Wresdiyati, 2004).

Serat dapat memberikan keuntungkan bagi kesehatan yaitu mengontrol berat badan atau kegemukan (obesitas), menanggulangi penyakit diabetes, mencegah gangguan gastrointestinal, kanker kolon (usus besar), serta mengurangi tingkat kolesterol darah dan penyakit kardiovaskuler (Santoso, 2011).

Hal ini sesuai dengan penelitian (Artanti, 2008) yang menyatakan bahwa ada hubungan antara asupan serat dengan 
trigliserida dalam darah. Semakin rendah asupan Serat, maka semakin tinggi kadar kolesterol total dan semakin tinggi asupan Serat semakin rendah kadar glukosa dan trigliserida darah hal ini menunjukkan ada hubungan asupan serat dengan penyakit diabetes dan kardiovaskular karena pengaruh dari kadar kolesterol dan glukosa yang dapat memicu peningkatan penyakit tersebut bila dikonsumsi secara berlebih tetapi asupan serat dapat membantu menurutkan kadar kolesterol, trigliserida dan kadar gula dalam darah (Kurniasari, 2014).

Rerata konsumsi sayur dan buah penduduk Indonesia masih rendah bila dibandingkan dengan anjuran kecukupan konsumsi sayur dan buah dalam konteks Gizi Seimbang. Demikian juga bila dilihat dari proporsinya, hampir semua penduduk kurang mengonsumsi sayur dan buah. Hal ini menunjukkan bahwa asupan serat masih rendah dan perlunya mengatur pola konsumsi pangan agar tercapai tingkat kecukupan energi dan zat gizi lain dengan baik sesuai dengan angka kecukupan yang dianjurkan khususnya serat (Prihatini, 2016).

Rebung salah satu makanan khas Bengkulu yang mengandung serat tinggi dan hanya diolah menjadi lauk sayuran, lemeah dan gulai santan. Rebung bambu adalah tunas muda dari bambu yang biasa digunakan dalam kuliner atau makanan tradisional masyarakat Indonesia dan merupakan salah satu jenis sayuran yang sudah lama dikenal dan dikonsumsi manusia. Rebung bambu memiliki tekstur renyah, rasanya manis, memiliki bau khas dan rebung juga sering dimanfaatkan sebagai makanan tradisional masyarakat (Andoko, 2003).

Rebung memiliki kandungan zat gizi dan potensi sebagai bahan makanan serta dapat dijadikan bahan substitusi maka rebung ini dapat diolah menjadi tepung yang dapat dimanfaatkan dan dapat mempermudah masyarakat dalam pengaplikasiannya sebagai bahan berbagai produk pangan (Puspaningrum, Nyoman, 2015).

Rebung yang telah dibuat tepung dapat disubstitusikan pada makananmakanan yang digemari oleh masyarakat, salah satunya adalah roti tawar. Roti tawar merupakan bahan pangan yang mudah dibuat, praktis, murah, mudah didapat, tahan lama dan mudah dimodifikasi untuk membuat jenis makanan yang lainnya, seperti sandwich, roti bakar dan lainnya. Dengan adanya roti tawar yang berbahan rebung , makan dapat meningkatan kandungan zat gizi pada roti tawar. Roti tawar mengandung karbohidrat cukup tinggi, sehingga bisa menjadi alternative lain sebagai sumber kalori, bahkan bagi kelurga tertentu roti sudah menjadi menu tetap untuk sarapan pagi dan memiliki 
harga yang relative terjangkau dikalangan masyarakat. (Habibah, 2009).

Berdasarkan latar belakang diatas maka penulis tertarik untuk meneliti pengaruh variasi konsentrasi tepung rebung pada pembuatan roti tawar. Penelitian ini bertujuan untuk mengetahui daya terima konsumen dengan $\mathrm{Uji}$ Organoleptik, umur simpan dan kadar serat terhadap pengaruh variasi konsentrasi tepung rebung pada pembuatan roti tawar.

\section{BAHAN DAN CARA KERJA}

Bahan yang digunakan dalam penelitian pengolahan tepung rebung adalah rebung betung (Dendrocalamus Asper). Rebung Betung diperoleh dari Kabupaten Lebong Kota Lebong. Penelitian ini dilakukan pada 08 Mei 2018. Bahan-bahan yang digunakan dalam penelitian ini adalah sebagai berikut : tepung terigu, rebung, gula, garam, susu, mentega putih, butter, air, bakery plus, ragi instan (fermifan), $\mathrm{H}_{2} \mathrm{SO}_{4} 1,25 \%$, $\mathrm{NaOH} 3,25 \%$, Etanol $96 \%$ dan Aquadest.

Alat-alat yang digunakan dalam penelitian ini adalah pisau, baskom, parutan, ayakan, loyang, cetakan kue. Alat ukur yang digunakan untuk mengukur bahan adalah sendok, timbangan, gelas ukur. Alat masak menggunakan oven dan uji kadar serat neraca Analitik, Spatula, Erlenmeyer $500 \mathrm{~mL}$, Pipet volume $50 \mathrm{~mL}$, Pendingin tegak, Hot plate, Corong Buchner, Kertas saring, Pompa, Beaker glass, Batang pengaduk, Oven, Cawan petri.

Penelitian ini menggunakan metode eksperimen untuk mengetahui kadar serat, umur simpan dan uji organoleptik. Penelitian dilakukan di Laboratorium Pangan Jurusan Gizi Poltekkes Kemenkes Bengkulu. Metode yang digunakan adalah Rancangan Acak Lengkap dengan 3 perlakuan yaitu F1, F2 dan F3.

$\mathrm{P} 1$ = Formulasi roti tawar tepung rebung dengan konsentrasi 0\% (0 gr dari 330 gr tepung terigu)

P2 =Formulasi roti tawar tepung rebung dengan konsentrasi $3 \%$ (10 gr dari 330 gr tepung terigu)

P3 = Formulasi roti tawar tepung rebung dengan konsentrasi $6 \%$ (20 gr dari 330 gr tepung terigu)

P4 = Formulasi roti tawar tepung rebung dengan konsentrasi $9 \%$ (30 gr dari 330 gr tepung terigu) 


\section{HASIL}

Tabel 1. Kandungan Kadar Serat Roti Tawar dengan Variasi Konsentrasi Tepung Rebung

\begin{tabular}{c|c|c}
\hline No. & Nama Sampel & Kadar Serat (\%) \\
\hline 1. & P1 & 0,60 \\
\hline 2. & P2 & 2,16 \\
\hline 3. & P3 & 2,35 \\
\hline 4. & P4 & 6,98 \\
\hline
\end{tabular}

Tabel 2. Daya Simpan Pada Roti Tawar

\begin{tabular}{c|c|c|c|c|c|c|c|c|c|c|c}
\hline No. & Sampel & $\begin{array}{l}\text { Hari } \\
\text { ke 1 }\end{array}$ & $\begin{array}{l}\text { Hari } \\
\text { ke 2 }\end{array}$ & $\begin{array}{l}\text { Hari } \\
\text { ke 3 }\end{array}$ & $\begin{array}{l}\text { Hari } \\
\text { ke 4 }\end{array}$ & $\begin{array}{c}\text { Hari } \\
\text { ke 5 }\end{array}$ & $\begin{array}{c}\text { Hari } \\
\text { ke 6 }\end{array}$ & $\begin{array}{c}\text { Hari } \\
\text { ke 7 }\end{array}$ & $\begin{array}{c}\text { Hari } \\
\text { ke 8 }\end{array}$ & $\begin{array}{c}\text { Hari } \\
\text { ke 9 }\end{array}$ & $\begin{array}{c}\text { Hari } \\
\text { ke 10 }\end{array}$ \\
\hline 1. & P1 & Tidak & Tidak & Tidak & Tidak & Ya & Ya & Ya & Ya & Ya & Ya \\
2. & P2 & Tidak & Tidak & Tidak & Tidak & Tidak & Ya & Ya & Ya & Ya & Ya \\
3. & P3 & Tidak & Tidak & Tidak & Tidak & Tidak & Tidak & Ya & Ya & Ya & Ya \\
4. & P4 & Tidak & Tidak & Tidak & Tidak & Tidak & Tidak & Ya & Ya & Ya & Ya \\
\hline
\end{tabular}

Tabel 3. Nilai Rata-Rata Uji Organoleptik Warna Roti Tawar dengan Penambahan Tepung Rebung

\begin{tabular}{c|c|c|c|c}
\hline $\begin{array}{c}\text { Nama } \\
\text { Sampel }\end{array}$ & $\begin{array}{c}\text { Nilai } \\
\text { Modus }\end{array}$ & $\begin{array}{c}\text { Nilai } \\
\text { Mean }\end{array}$ & $\begin{array}{c}\text { Uji Man } \\
\text { Whitney }\end{array}$ & $\begin{array}{c}\text { Uji Kruskall } \\
\text { Wallis }\end{array}$ \\
\hline P1 & 4 & 4.18 & A & \multirow{2}{*}{0.000} \\
\cline { 1 - 2 } P2 & 4 & 3.68 & B & \\
\cline { 1 - 2 } P3 & 3 & 3.32 & C & \\
\hline
\end{tabular}

Keterangan : (a) menunjukkan tidak ada perbedaan nyata pada taraf 5\% (p) menurut Uji Man Whitney (b) dan (c) menunjukkan ada perbedaan nyata pada taraf $5 \%$ (p) menurut Uji Man Whitney 
Tabel 4. Nilai Rata-Rata Uji Organoleptik Aroma Roti Tawar dengan Penambahan

Tepung Rebung

\begin{tabular}{c|c|c|c|c}
\hline $\begin{array}{c}\text { Nama } \\
\text { Sampel }\end{array}$ & $\begin{array}{c}\text { Nilai } \\
\text { Modus }\end{array}$ & $\begin{array}{c}\text { Nilai } \\
\text { Mean }\end{array}$ & $\begin{array}{c}\text { Uji Man } \\
\text { Whitney }\end{array}$ & $\begin{array}{c}\text { Uji } \\
\text { Kruskall } \\
\text { Wallis }\end{array}$ \\
\hline P1 & 4 & 3.60 & A & \multirow{2}{*}{0.290} \\
\hline P2 & 4 & 3.52 & A & \\
\hline P3 & 3 & 3.35 & A & \\
\hline P4 & 3 & 3.45 & A &
\end{tabular}

Keterangan : (a) menunjukkan tidak ada perbedaan nyata pada taraf $5 \%$ (p) menurut Uji Man Whitney

Tabel 5. Nilai Rata-Rata Uji Organoleptik Aroma Roti Tawar dengan Penambahan Tepung Rebung

\begin{tabular}{c|c|c|c|c}
\hline $\begin{array}{c}\text { Nama } \\
\text { Sampel }\end{array}$ & $\begin{array}{c}\text { Nilai } \\
\text { Modus }\end{array}$ & Nilai Mean & $\begin{array}{c}\text { Uji Man } \\
\text { Whitney }\end{array}$ & $\begin{array}{c}\text { Uji Kruskall } \\
\text { Wallis }\end{array}$ \\
\hline P1 & 4 & 3.90 & A & \multirow{2}{*}{0.670} \\
\cline { 1 - 2 } P2 & 4 & 3.98 & A & \\
\hline P3 & 4 & 3.80 & A & \\
\hline
\end{tabular}

Keterangan : (a) menunjukkan tidak ada perbedaan nyata pada taraf 5\% (p) menurut Uji Man Whitney

Tabel 6. Nilai Rata-Rata Uji Organoleptik Tekstur Roti Tawar dengan Penambahan Tepung Rebung

\begin{tabular}{c|c|c|c|c}
\hline $\begin{array}{c}\text { Nama } \\
\text { Sampel }\end{array}$ & $\begin{array}{c}\text { Nilai } \\
\text { Modus }\end{array}$ & Nilai Mean & $\begin{array}{c}\text { Uji Man } \\
\text { Whitney }\end{array}$ & $\begin{array}{c}\text { Uji } \\
\text { Kruskall } \\
\text { Wallis }\end{array}$ \\
\hline P1 & 4 & 3.95 & A & \multirow{2}{*}{0.208} \\
\hline P2 & 4 & 3.90 & A & \\
\hline P4 & 4 & 3.60 & A & \\
\hline
\end{tabular}

Keterangan : (a) menunjukkan tidak ada perbedaan nyata pada taraf 5\% (p) menurut Uji Man Whitney 


\section{PEMBAHASAN}

\section{Kadar Serat}

\section{Bedasarkan hasil penelitian diketahui bahwa semakin banyak penambahan tepung rebung maka kadar serat roti tawar semakin besar.} Peningkatan kadar serat dapat disebabkan oleh nilai kadar serat dalam 100 gram rebung adalah 3,14\% (Kencana, Widia, \& Antara, 2009).

Berdasarkan USDA Food Composition Databases 2016 kadar serat roti tawar per 100 gram yaitu $2,7 \%$ sedangkan berdasarkan hasil uji analisis serat kasar pada roti tawar dengan penambahan tepung rebung yaitu P1 $0,60 \%$, P2 2,16\%, P3 2,35\% dan P4 6,98\%. Hal ini disebabkan oleh penambahan tepung rebung pada masingmasing perlakuan yang juga meningkat. Sehingga diketahui bahwa roti tawar tepung rebung sudah sesuai dengan standar USDA yaitu P2 dan P3. Dalam hal ini rebung merupakan jenis pangan yang memiliki kandungan serat yang cukup tinggi. Hasil penelitian ini sejalan dengan pendapat Mastrina dkk (2017) yang menyatakan bahwa semakin tinggi penambahan rebung dalam pembuatan nugget maka kadar serat yang dihasilkan semakin tinggi yaitu sebesar 9,20\%.

Serat atau fiber adalah zat non gizi yang banyak terdaat pada sayuran, buah dan kacang-kacangan. Serat berfungsi untuk membantu proses pencernaan, mencegah sembelit, kanker, mencegah kegemukan, menurunkan kadar kolesterol, mengatur kadar gula dalam darah, mencegah wasir, mencegah dan mengobati penyakit tidak menular seperti hipertensi, jantung dan diabetes serta memperlancar buang air besar(Muchtar, 2010). Oleh karena itu roti tawar bisa dijadikan salah satu alternatif makanan dengan penambahan serat yang bisa dikonsumsi masyarakat karena roti tawar dengan penambahan tepung rebung memiliki kadar serat yang cukup tinggi. Dalam hal ini tepung rebung dapat dimanfaatkan lebih lanjut untuk pengolahan pangan lain dengan harapan dapat meningkatkan nilai serat dari suatu produk pangan. Semakin tinggi penambahan tepung rebung maka semakin tinggi pula nilai kadar serat.

\section{Umur Simpan}

Berdasarkan hasil penelitian didapatkan bahwa roti tawar yang disimpan selama 10 hari mulai berjamur pada hari ke 5 untuk P1, P2 hari ke 6, P3 dan P4 pada hari ke 7. Saat berjamur aroma pada roti tawar sudah tengik dan mulai tampak benang-benang jamur berwarna hijau hingga akhirnya menjadi kehitaman.

$$
\text { Jamur merupakan mikro }
$$
organisme utama yang berperan penting 
dalam proses pembuatan dan pembusukan roti. Menurut Kusuma, tepung terigu yang menjadi bahan dasar dalam pembuatan roti tawar mengandung pati dalam jumlah yang relatif tinggi. Pati ini dapat dihidrolisis menjadi gula sederhana oleh mikroorganisme khususnya jamur, karena gula sederhana merupakan sumber nutrisi utama bagi mikroorganisme tersebut (Kusuma, 2008).

Dalam penelitian ini semakin banyak penambahan tepung rebung pada pembuatan roti tawar maka semakin lama roti tawar berjamur dan sebaliknya untuk roti tawar tanpa penambahan tepung rebung mengalami penjamuran lebih cepat. Hal ini sejalan dengan Dina dkk bahwa semakin tinggi kandungan tepung terigu maka pertumbuhan jamur relatif cepat (Mizana, Suharti, \& Amir, 2016).

Namun dalam proses pembusukan roti tawar tidak semata hanya disebabkan bahan utama pembuatannya tetapi juga berpengaruh terhadap suhu, kebersihan dan lama penyimpanannya (Babay, 2013).

\section{Uji Organoleptik (Warna)}

Berdasarkan hasil penelitian didapatkan bahwa ada pengaruh variasi konsentrasi tepung rebung terhadap mutu organoleptik warna roti tawar. Semakin tinggi tingkat variasi konsentrasi tepung rebung maka semakin rendah tingkat kesukaan panelis terhadap warna roti tawar. Hal ini terjadi karena adanya perbedaan tingkat konsentrasi penambahan tepung rebung pada setiap perlakuan sehingga menghasilkan warna yang berbeda, semakin tinggi tingkat konsentrasi tepung rebung maka warna roti tawar semakin coklat.

Warna coklat dikarenakan pengaruh dari tepung rebung yang berwarna putih kecoklatan apabila dicampur akan menyebabkan adonan berwarna coklat. Warna tersebut diakibatkan pada saat proses pengeringan, rebung yang telah dipotong-potong akan mengalami reaksi pencoklatan enzimatis meskipun telah direbus. Perubahan ini terjadi dikarenakan adanya reaksi non enzimatis yang terjadi antara asam organik dengan gula pereduksi dan antara asam amino dengan gula pereduksi, yang di sebut dengan reaksi maillard. Menurut Eskin et al., (Wirananda, 2011)

Pengeringan adalah suatu metode untuk mengeluarkan atau menghilangkan sebagian air dari suatu bahan dengan cara menguapkan air tersebut dengan menggunakan energi panas (Riansyah, Supriadi, \& Nopianti, 2013). Warna merupakan sensori pertama yang dapat dilihat langsung oleh panelis. penentuan mutu bahan makanan umumnya bergantung pada warna yang dimilikinya, warna yang tidak menyimpang dari warna yang seharusnya akan memberi kesan 
penilaian tersendiri oleh panelis (Arifin, Oktaviana, Wihansah, \& Yusuf, 2016).

Dari hasil pengamatan uji organoleptik warna pada roti tawar terlihat dari 40 panelis lebih menyukai roti tawar perlakuan P1 dengan konsentrasi 0\% tanpa penambahan tepung rebung yaitu $53 \%$ suka sebanyak 21 orang $33 \%$ sangat suka sebanyak 13 orang. Jadi panelis lebih menyukai warna roti tawar yang putih seperti warna roti tawar pada umumnya.

\section{Uji Organoleptik (Aroma)}

Berdasarkan hasil penelitian didapatkan bahwa tidak ada pengaruh variasi konsentrasi tepung rebung terhadap mutu organoleptik aroma roti tawar. Dalam penelitian ini rebung memiliki aroma yang khas, menurut Kencana dkk. (2012) komponen yang terkandung di dalam rebung berupa asam hexadecanote dan asam octadecadienote sebagai senyawa penyusun aroma rebung.

Aroma adalah bau yang ditimbulkan oleh rangsangan kimia yang tercium oleh syaraf-syaraf olfaktori yang berada dalam rongga hidung(Arifin et al., 2016). Dari hasil pengamatan uji organoleptik aroma pada roti tawar terlihat dari 40 panelis lebih menyukai roti tawar perlakuan P1 dengan konsentrasi 0\% tanpa penambahan tepung rebung yaitu 53\% suka sebanyak 21. Pembuatan roti tawar semua campuran bahan yang digunakan ukurannya sama, serta suhu dan waktu pengovenan juga sama. Campuran bahan tersebut akan menghasilkan aroma sedap yang memperkuat aroma khas roti (Muthohiroh \& Sulandjari, 2015).

Jadi meskipun penambahan tepung rebung telah ditambahkan dalam jumlah besar hasilnya akan tetap tidak berpengaruh terhadap aroma roti tawar karena akan tertutupi atau akan kalah dengan aroma dari bahan campuran roti tawar.

\section{Uji Organoleptik (Rasa)}

Berdasarkan hasil penelitian didapatkan bahwa tidak ada pengaruh variasi konsentrasi tepung rebung terhadap mutu organoleptik rasa roti tawar. Menurut Nengah (2015) kelemahan rebung sebagai bahan makanan adalah kandungan sianidanya yang tinggi. Kandungan sianida pada rebung dapat menimbulkan rasa pahit, namun dengan adanya pemanasan dan pengolahan dapat menurunkan kandungan sianida pada rebung sehingga tidak mempengaruhi rasa pada roti tawar yang dihasilkan (Silaban, Herawati, \& Zalfiatri, 2017).

Persepsi cita rasa merupakan tanggapan indera terhadap rangsangan saraf, seperti pahit atau manis pada indera pengecap. Selain dipengaruhi oleh indera pengecap, persepsi cita rasa juga dapat 
dipengaruhi oleh kemampuan visual individu (Langgeng \& Widiana, 2013).

Dari hasil pengamatan uji organoleptik rasa pada roti tawar terlihat dari 40 panelis lebih menyukai roti tawar perlakuan P2 dengan konsentrasi $3 \%$ penambahan tepung rebung yaitu $75 \%$ suka sebanyak 30 orang. Saat penelitian rasa ke empat perlakuan roti tawar memiliki rasa yang sama. Hal ini terjadi karena ada faktor lain yang mempengaruhi yaitu penurunan kadar sianida pada rebung dan penambahan pada bahan pembuatan roti tawar yang digunakan ukurannya sama, serta suhu dan waktu pengovenan sama juga. Sehingga hasil rasa antar 4 produk roti tawar dengan penambahan tepung rebung reatif sama.

\section{Uji Organoleptik (Tekstur)}

Berdasarkan hasil penelitian didapatkan bahwa tidak ada pengaruh variasi konsentrasi tepung rebung terhadap mutu organoleptik tekstur roti tawar. Dari hasil pengamatan uji organoleptik tekstur pada roti tawar terlihat dari 40 panelis lebih menyukai roti tawar perlakuan P2 dengan konsentrasi $3 \%$ tepung rebung yaitu $55 \%$ suka sebanyak 22 orang.

Tekstur merupakan sensasi tekanan yang dapat diamati dengan mulut (pada waktu digigit, dikunyah dan ditelan) ataupun perabaan dengan jari. Kualitas utama dari roti tawar ditentukan oleh tekstur, Perbedaan tekstur roti tawar yang dihasilkan pada penelitian ini dipengaruhi oleh tepung rebung yang digunakan. Serat pada tepung rebung berfungsi mengikat air sehingga roti yang dihasilkan tidak terlalu mengembang. Penggunaan tepung rebung menyebabkan pengembangan yang kurang baik atau menurunkan volume roti sehingga roti tawar yang dihasilkan tidak terlalu mengembang dan semakin tinggi tingkat konsentrasi tepung rebung maka akan semakin menyusut. Penyusutan ini terjadi karena tingkat kadar serat yang tinggi pada tepung rebung(Haryani et al., 2014).

\section{KESIMPULAN}

Penambahan variasi konsentrasi tepung rebung (P1, P2, P3 dan $\mathrm{P} 4)$ terhadap kadar serat pada pembuatan roti tawar menghasilkan kadar serat yang paling tinggi adalah $6,98 \%$ dengan konsentrasi 9\%. Umur simpan pada roti tawar dengan penambahan tepung rebung relatif lebih lama daripada roti tawar tanpa penambahan tepung rebung. Penambahan variasi konsentrasi tepung rebung $(\mathrm{P} 1, \mathrm{P} 2$, P3 dan P4) berpengaruh terhadap uji organoleptik warna roti tawar. Warna yang paling disukai yaitu roti tawar dengan penambahan konsentrasi rebung P1. Sedangkan Penambahan variasi konsentrasi tepung rebung (P1, P2, P3 dan 
P4) tidak berpengaruh terhadap uji organoleptik aroma, rasa dan tekstur roti tawar. Aroma yang paling disukai yaitu $\mathrm{P} 1$, rasa yang paling disukai yaitu roti tawar dengan penambahan konsentrasi rebung P2 dan tekstur yang paling disukai yaitu roti tawar dengan penambahan konsentrasi rebung P2.

Diharapkan Penelitian ini dapat dilanjutkan dengan melihat pengaruh penambahan variasi kosentrasi tepung rebung terhadap kadar air pada pembuatan roti tawar.

\section{DAFTAR PUSTAKA.}

Andoko, A. (2003). Budi Daya Bambu Rebung. Yogyakarta: Kanisius.

Arifin, Oktaviana, Wihansah, \& Yusuf. (2016). Aspek Mikrobiologis serta Sensori ( Rasa , Warna , Tekstur , Aroma ) pada Dua Bentuk Penyajian Keju yang Berbeda. Jurnal Ilmu Produksi Dan Teknologi Hasil Peternakan, 4(2), 286-290.

Habibah, S. N. (2009). Teknik Pembuatan Roti. Bandung: CV.Alfarisi Putra.

Haryani, M., Widawati, L., Sari, E. R., Teknologi, S., Fakultas, P., \& Unived, P. (2014). Modified Bamboo Shoots Flour As Wheat Substituent in Fiber Rich Donut Making. Agritepa, 1(1).

Kementrian Kesehatan RI. (2017). Tingkatkan Konsumsi Sayur dan Buah Nusantara Menuju Masyarakat Hidup Sehat - Sehat Negeriku. Www.depkes.go.id. Retrieved from Diakses 01 Desember 2017

Kencana, D., Widia, W., \& Antara, N. S.
(2009). Kandungan Nutrisi dan Senyawa Bioaktif Rebung Bambu Tabah yang Dibudidayakan di Desa PupuanTabanan, 20. Retrieved from http://seafast.ipb.ac.id/tpcproject/wpcontent/uploads/2014/03/RSC-

Komponen-nutrisi-bioaktifrebung-bambu-tabah.pdf

Kurniasari, R. (2014). Hubungan Asupan Karbohidrat, Lemak, dan Serat dengan Kadar Glukosa dan Trigliserida Darah Pada Pasien DM Tipe II Rawat Inap Di RSUP H.Adam Malik Medan. Wahana Inovasi, 3(1), 1-5.

Kusuma R. Pengaruh penggunaan cengkeh (Syzygium aromaticum) dan kayu manis (Cinnamomum) sebagai pengawet alami terhadap daya simpan roti manis (skripsi). Bogor: Institut Pertanian Bogor; 2008.

Made Astawan dan Tutik Wresdiyati. (2004). Diet Sehat dengan Makanan Berserat. Solo: Tiga Serangkai.

Mizana, D. K., Suharti, N., \& Amir, A. (2016). Identifikasi Pertumbuhan Jamur Aspergillus Sp pada Roti Tawar yang Dijual di Kota Padang Berdasarkan Suhu dan Lama Penyimpanan. Jurnal Kesehatan Andalas, 5(2), 355-360.

Muchtar. (2010). Be Healthy Be Happy. Jakarta: PT Bhuana Ilmu Populer.

Muthohiroh, M., \& Sulandjari, S. (2015). Pengaruh Penambahan Tepung Rebung Dan Penambahan Tahu Terhadap Mutu Organoleptik Nugget Mureta. E-Journal Boga, $4(2), 9-17$.

Prihatini, H. (2016). Gambaran Konsumsi Sayur dan Buah Penduduk Indonesia dalam Konteks Gizi Seimbang: Analisis Lanjut Survei Konsumsi Makanan Individu ( SKMI ) 2014. Buletin 
Penelitian Kesehatan, 44(3), 410.

Puspitasari, D. S., Julianti, E. D., Safitri,

A., \& Permanasari, Y. (2014).

Survai Konsumsi Makanan

Individu Dalam Studi Diet Total.

Jakarta: Menteri Kesehatan Rakyat Indonesia.

Riansyah, A., Supriadi, A., \& Nopianti, R. (2013). Pengaruh Perbedaan Suhu Dan Waktu Pengeringan Terhadap Karakteristik Ikan sin Sepat Siam (Trichogaster pectoralis) Dengan Menggunakan Oven. Fishtech,
2(1), 53-68.

Santoso, A. (2011). Serat Pangan (Dietary Fiber) dan Manfaatnya Bagi Kesehatan. Magistra, (75), 3540.

Silaban, M., Herawati, N., \& Zalfiatri, Y. (2017). Pengaruh Penambahan Rebung Dalam Pembuatan Nugget Ikan Patin (Pangasius hypothalamus). Jom Faperta, 4(2), 1-13.

Wirananda, D. (2011). Studi pembuatan kerupuk rebung. Medan: Departemen Teknologi Pertanian 